\title{
Correction: Kramer, R.A., et al. A Randomized Longitudinal Factorial Design to Assess Malaria Vector Control and Disease Management Interventions in Rural Tanzania. Int. J. Environ. Res. Public Health 2014, 11, 5317-5332
}

\author{
Randall A. Kramer ${ }^{1,2}$, Leonard E. G. Mboera ${ }^{3}$, Kesheni Senkoro ${ }^{3}$, Adriane Lesser ${ }^{1}$, \\ Elizabeth H. Shayo ${ }^{3}$, Christopher J. Paul ${ }^{1,2}$ and Marie Lynn Miranda ${ }^{4,5, *}$ \\ 1 Duke Global Health Institute, Duke University, 310 Trent Drive, Durham, NC 27710, USA; \\ E-Mails: kramer@duke.edu (R.A.K.); adriane.lesser@duke.edu (A.L.); \\ christopher.paul@duke.edu (C.J.P.) \\ 2 Nicholas School of the Environment, Duke University, 9 Circuit Drive, Durham, NC 27708, USA \\ 3 National Institute for Medical Research, 2448 Barack Obama Drive, P.O. Box 9653, Dar es Salaam, \\ Tanzania; E-Mails: 1mboera@nimr.or.tz (L.E.G.M.); ksenkoro@nimr.or.tz_(K.S.); \\ eshayo@nimr.or.tz (E.H.S.) \\ 4 School of Natural Resources and Environment, University of Michigan, 440 Church Street, Ann \\ Arbor, MI 48109, USA \\ 5 Departments of Pediatrics and Obstetrics \& Gynecology, School of Medicine, University of \\ Michigan, Ann Arbor, MI 48109, USA
}

* Author to whom correspondence should be addressed; E-Mail: mlmirand@umich.edu.

Received: 10 July 2014 / Accepted: 18 July 2014 / Published: 25 August 2014

The authors wish to make the following corrections to their paper published in the International Journal of Environmental Research and Public Health [1]:

Page 5326, line 24, the sentence "Larviciding was done with the microbial agent of bacterial pathogens Bacillus thuringiensis var. israelensis (Bti) (Bactivec ${ }^{\circledR}$, ValentBioSciences (VBS, Libertyville, IL, USA), CG formulation)." should read "Larviciding was done with a granular formulation (VectoBac ${ }^{\circledR} \mathrm{CG}$ ) of the bacterial larvicide (BL) Bacillus thuringiensis var. israelensis (Bti) strain AM65-52, Valent BioSciences Corporation (VBC, Libertyville, IL, USA)”.

The authors would like to apologize for any inconvenience caused to readers by these changes. 


\section{Reference}

1. Kramer, R.A.; Mboera, L.E.G.; Senkoro, K.; Lesser, A.; Shayo, E.H.; Paul, C.J.; Miranda, M.L. A randomized longitudinal factorial design to assess malaria vector control and disease management interventions in rural Tanzania. Int. J. Environ. Res. Public Health 2014, 11, $5317-5332$.

(C) 2014 by the authors; licensee MDPI, Basel, Switzerland. This article is an open access article distributed under the terms and conditions of the Creative Commons Attribution license (http://creativecommons.org/licenses/by/3.0/). 